\title{
The Effects of Inward and Outward Foreign Direct Investments on Economic Growth: Evidence from the G-7 and Selected Emerging Market Economies (1994-2015)
}

\author{
Ömer Yalçınkaya ${ }^{1, *} \&$ Halil İbrahim Aydın² \\ ${ }^{1}$ Department of Economics, Agri Ibrahim Çeçen University, Ağri, Turkey \\ ${ }^{2}$ Department of Economics, Batman University, Batman, Turkey \\ *Corresponding author: Department of Economics, The Faculty of Economics and \\ Administrative Science, Agri Ibrahim Çeçen University, Ağrı, Turkey. E-mail: \\ omeryalcinkaya84@hotmail.com
}

Received: March 26, 2017 Accepted: March 29, 2017 Published: March 31, 2017

doi:10.5296/rae.v9i1.10986 URL: https://doi.org/10.5296/rae.v9i1.10986

\begin{abstract}
In this study, the long termed effects of foreign direct (capital) investments inflows and outflows on the economic growth of the economies of developed G-7 countries where the capital mobility is intense and selected emerging market economies (Brazil, China, India, Mexico, Russia, South Africa and Turkey (EME-7)) are empirically analyzed for the period of 1994-2015 within the scope of the new generation panel data methodology. From this aspect, it is also aimed to economically analyze whether the foreign direct investments inflows and outflows in countries of G-7 and EME-7 have an effect on the economic growth as is seen in the theoretical framework by being considered the capital exporter/importer positions of these countries. Determined in consequence of the study that foreign direct investments inflows/outflows in the countries of G-7 have a positive and statistically significant effect on economic growth in the long term. Also determined that the foreign direct investments inflows have a positive and statistically significant effect on economic growth in countries of EME-7; while the foreign direct investments outflows have not the same effect on the economic growth. These results which are consonant with the theoretical and empirical literature show that just both foreign direct investments inflows and outflows have a significant role in economic growth on G-7 countries; just foreign direct investments inflows have an important role in economic growth on EME-7 countries at the same time.
\end{abstract}

Keywords: Foreign Direct (Capital) Investments Inflows and Outflows, Economic Growth, G-7 and Selected Emerging Market Economies, New Generation Panel Data Analysis 


\section{Introduction}

The fluctuations have happened in economic, political and socio-cultural fields since the second half of the twentieth century remove the closed economy macro models and bring the national economies closer to each other day by day. The scarce resources around the world, remarkable developments in technology area by the profit fact of the producer and utility maximizing fact of the consumer reveal the globalization fact and move efforts to increase/expand production possibilities of countries which follow opened economy macro models beyond the borders. Being famous of the globalization and liberalization trends across the globe within the process make the foreign direct investments enable for efficient distribution and use of the scarce resources in national economies one of the crucial transfrontier economic activity (Bayraktar, 2003:1-2).

Indeed, the foreign direct investments inflows provide the capital importer countries with opportunity to close their national the saving gaps, increase the domestic fixed capital investments and increase the capacity of goods and services exportation, improve the labor qualification by the level of employment and enhance the national competitiveness by benefiting from innovative methods based on the technological developments. However, the foreign direct investments outflows contribute to the capital exporter countries to use their national over savings, expand the fixed capital investments abroad, enhance the goods and services exportation and increase the international competitiveness as well. From this aspect, the foreign direct investment inflows/outflows pave the way for capital importer/exporter countries to be relatively increased the Real Gross Domestic Product (GNP) and Real Gross National Products (GNP) by improving the investment and production possibilities at home or abroad. When the national-international price levels are the data, the increments in GDP of capital importer countries and GNP of capital exporter ones accelerate their growth rates/wealth levels and increase the global competitiveness either.

From this point of view, the long termed effects foreign direct investments inflows and outflows on the economic growth of the economies of developed G-7 countries where the capital mobility is intense and selected emerging market economies (Brazil, China, India, Mexico, Russia, South Africa and Turkey (EME-7)) are econometrically analyzed for the period of 1994-2015. Moreover, the relations between foreign direct investments inflow and outflows in groups of G-7 with EME-7 and the economic growth are reviewed by being considered the effects of foreign direct investments inflows on real GDP and the effects of outflows of real GNP. It is also aimed to econometrically analyze whether the foreign direct investments inflows and outflows in countries of G-7 and EME-7 have an effect on the economic growth as is seen in the theoretical framework by being considered the capital exporter/importer positions of these countries. It is thought that the findings of this research conducted by considering the capital exporter/importer positions and the differences of development level of countries in groups of G-7 and EME-7 contribute for the improvement the related literature.

In this research, this relevant literature is summarized with the broad outlines and the position of the study in literature is explained in second part following the introduction. In the third 
part, it is sketched the methodology of the research in and econometrically analyzed the effects of foreign direct investments inflow/outflows on the economic growth for the period of 1994-2015. The study is completed by the fourth and last part includes the general assessments.

\section{Literature Summary and the Position of the Research in Literature}

In related literature, studies on theoretical and empirical level mostly analyzed the foreign direct investments inflows on the economic growth (real GDP) of capital importer countries. In empirical studies based on internal growth models, the effects of foreign direct investments inflows on the economic growth are accepted as a function of technological processes; and stated that these effects have a positive impact on the economic growth of capital importer countries by revealing the deployment power of technological developments in the long term. In empirical studies conducted in different countries or country groups within the scope of the cross section, time series and panel data analysis methodology since 1990s, it is reached the end of the long termed effects of foreign direct investments inflows in capital importer countries on real GDP generally positive and statistically significant. (Balasubramanyam et al., (1996), Borensztein et al., (1998), Bosworth and Collins (1999), De Mello (1999), Obwona (2001), Kumar and Pradhan (2002), Hermes and Lensink (2003), Li and Liu (2004), Khawar (2005), Lensink and Morrisey (2006), Alfaro and Charton (2007), Mun et al., (2008), Chowdhary and Kushwaha (2013), Zekarias (2016)). These results most of which were obtained from studies conducted in developing countries empirically bear the thought of the foreign direct investment inflows have positive effects on economic growth of capital importer countries as is predicted in theoretical framework out. However, determined in some other studies within the same scope that the long-term effects of foreign direct investment inflows on real GDP in the capital importer countries are negative and statistically significant/insignificant. (Carkovic and Levine, (2002), Lensink and Morrisey (2006), Sarkar (2007)). These results indicate that the positive effects of foreign direct investment inflows on economic growth are not absolute in capital importer countries and these effects tend to change according to some characteristics such as investment environment, internalization capacity of new technologies, degree of integration with external world, qualification of human capital, economic development level, etc. Besides, it is seen that there are a limited number of studies review the effects of foreign direct investments outflows on economic growth (real GDP) in capital exporter countries and no studies examine these effects on real GNP. Proved by the help of the empirical studies conducted over the past decade in different countries within the scope of time series, panel data analysis methodology that the long termed effects of foreign direct investments outwards in capital exporter countries on real GDP is positive and statistically significant. (Herzer (2008 (Note 1)), Lee (2010a-Japan), Lee (2010b-Singapore), Chen and Zulkifli (2012-Malaysia), Behbehani and Hallaq (2013-Kuwait), Al-Shawaf and Almsafir (2016-Malaysia), Panyagometh (2016-Thailand)).

Seen in the studies conducted in developing countries that just the effects of foreign direct investment inflows of capital importer countries on real GDP are considered, not the 
development level differences of countries. It is followed at the same time that there are a limited number of studies in literature review the effects of foreign direct investments on the real GDP and also not to be considered the capital exporter status of countries. The expansionary effects of direct foreign investment outflows on domestic production possibilities (Outward FDI) actualizing as relatively limited and on real GDP as indirect while these expansionary effects on overseas production possibilities actualize as relatively unlimited and on real GNP as direct. We can think when taking into account all these circumstances that analyzing the effects of foreign direct investment outflows of capital exporter countries on real GNP instead of real GDP can produce more consistent results. Within this framework, the connections between foreign direct investment inflows and outflows and the economic growth of the groups of G-7 and EME-7, effects of foreign direct investment inflows on real GDP and effects of foreign direct investment outflows on real GNP are investigated in this research. Thought that this study conducted by being considering the development level differences and capital exporter-importer status of countries in G-7 and EME-7 groups could contribute to the improvement of literature that has just started to ingenerate.

\section{Data, Methodology, and Findings of the Research}

In this part of the study, the effects of foreign direct investment inflow and outflows on economic growth for developed G-7 countries and selected emerging market economies (EME-7) are reviewed econometrically for the period of 1994-2015. (Note 2) The variables in models used to predict the effects of foreign direct investment inflows on real GDP and outflows on real GNP are explained in Table 1. (Note 3)

Table 1. Variables in Models and Sources

\begin{tabular}{|c|c|c|}
\hline $\begin{array}{c}\text { The Abridgment of } \\
\text { Variables }\end{array}$ & The Definition of Variables & Data Sources \\
\hline PCRGDP & Per Capita Real GDP 2011 (USD) & \multirow{6}{*}{$\begin{array}{c}\text { The World Bank (WB) } \\
\text { (World Development } \\
\text { Indicators-2017). }\end{array}$} \\
\hline PCRGNP & Per Capita Real GNP 2011 (USD) & \\
\hline RGFCF & Real Fixed Capital Investments 2010 (USD) & \\
\hline OR & Openness Ratio 2010 (USD) & \\
\hline INFDI & Inward Foreign Direct Investments (USD) & \\
\hline OUTFDI & Outward Foreign Direct Investments (USD) & \\
\hline EL & Employed Labour Force & $\begin{array}{c}\text { The Conference Board } \\
\text { (Total Economy } \\
\text { Database, May-2016). }\end{array}$ \\
\hline
\end{tabular}

Panel data analysis searches the effects of foreign direct investment inflows and outflows on economic growth due to being used the times series data of countries in G-7 and EME-7 group together and also aimed to determine the direction/size of the relations between the series. Variables of physical human capital accumulation and openness rate control and the 
models used for review the effects of foreign direct investment inflows on real GDP per capita and the effects of foreign direct investment outflows on real GNP per capita are shown in below equations: (Note 4)

Model 1: $P C R G D P_{i t}=\alpha_{i t}+\beta_{1} R G F C F_{i t}+\beta_{2} E L_{i t}+\beta_{3} O R_{i t}+\beta_{3} I N F D I_{i t}+u_{i t}$

Model 2: $P C R G N P_{i t}=\alpha_{i t}+\beta_{1} R G F C F_{i t}+\beta_{2} E L_{i t}+\beta_{3} O R_{i t}+\beta_{3} O U T F D I_{i t}+u_{i t}$

In models, the terms of $(\alpha),(\beta),(\mathrm{u}),(\mathrm{i}),(\mathrm{t})$ respectively represent the constant parameter, slope parameters, residuals, cross section units and the year. The steady state of the series in panel data methodology is essential; $t, F$ and $R^{2}$ test statistical values can be found when an analysis made by non-stationary series. Therefore, the steady state of series must firstly be analyzed to avoid the spurious regression and obtain consistent results (Tatoğlu, 2013:199). The unit root tests used to determine the stationarity of the panel data divided into two groups as first and second generation based on the existence of cross section dependence. The section created the series in first and second generation panel unit root tests assume that the units are respectively independent of each other and interdependent. When being assumed in first generation panel unit root tests that all the units affected at the same rate from a shock happened just in one section; accepted in second generation panel unit root tests that each unit effects at different ratios from the same shock. Within this scope, the first generation panel unit root tests (Hadri 2000, Levin et al., 2002, Im et al., 2003, Breitung 2005 et al.,) do not provide consistent results in case of being the cross section dependence; and the second generation panel unit root tests allow for (Taylor and Sarno 1998, Breuer et al., 2002, Pesaran 2007, Hadri and Kurozumi, 2012 et al.), the cross section dependence should be used. Consequently, in panel data studies, the cross section dependence in cointegration equation of the model or series in the model should be analyzed before estimating the models, then the unit root and the following tests used in analyses should be specified. Tests used may create biased and inconsistent results.

Moreover, the time and section scale of the series must be considered when the cross section independence in pane data is analyzed. CD-LMadj test of Pesaran et al., (2008) can be used in cases of being the time dimension of series bigger $(\mathrm{T}>\mathrm{N})$ and smaller $(\mathrm{T}<\mathrm{N})$ than the section dimension, and in the case of being the time dimension equal $(\mathrm{T}=\mathrm{N})$ to the section dimension as well. The test statistics may provide consistent results in all conditions in which the individual average different from zero due to being added the average and the variance of the cross sections into the test statistics called as CD-LM test. (Pesaran et al., 2008:105-127). The existence of the cross-section dependency in CD-LMadj test is researched by the alternative hypothesis called 'there is cross section dependence in series or model' as opposed to the primary hypothesis called 'there is not the cross section dependence in series or model.' In $\mathrm{CD}-\mathrm{LM}_{\mathrm{adj}}$ test which is assumed as showing the asymptotically normal distribution, the existence of cross section dependence in series or model is accepted in case of being denied the basic hypothesis. CD-LMadj test examines the presence of the cross section dependence in series in models and cointegration equations defined for the groups of G-7 and EME-7 and Table 2 shows the results. 
It can be easily seen when the results in Table 2 are analyzed regarding the variables in models in G-7 and EME-7 groups that all variables are intercept and the possibilities of $\mathrm{CD}-\mathrm{LM}_{\mathrm{adj}}$ test statistics in intercept+trend form are less than 0,01. In this case, the primary hypothesizes created in terms of CD-LM $\mathrm{Ldj}_{\text {adj }}$ test for all variables in the groups of G-7 and EME-7 should be denied. Followed when the test results in Table 2 are analyzed in terms of cointegration equations of models in groups of G-7 and EME-7 that the possibilities of CD-LMadj test statistics calculated in forms of intercept and intercept+trend for models defined in both country groups are bigger than 0,05 . In such a case, the basic hypothesizes created in terms of CD-LMadj test for the cointegration equations of models defined in G-7 and EME-7 groups should be accepted. These results indicate that there is the cross section dependence between cross-section units in terms of the variables in models described in the groups of G-7 and EME-7, on the other hand, the cross section independence of established models regarding the co-integration equations can be understood via the same results.

Table 2. Results of Cross Section Independence Test

\begin{tabular}{|c|c|c|c|c|c|c|c|c|}
\hline \multirow[b]{2}{*}{ Variables } & & $\mathrm{M}_{\mathrm{a}}$ & $\begin{array}{l}\text { J-7 } \\
\text { dj Statistics }\end{array}$ & & & $\mathrm{LM}$ & $\begin{array}{l}\text { IE-7 } \\
\text { dj Statistics }\end{array}$ & \\
\hline & Intercept & $\mathrm{L}$ & Intercept+Trend & $\mathrm{L}$ & Intercept & $\mathrm{L}$ & Intercept+Trend & $\mathrm{L}$ \\
\hline PCRGDP & $\begin{array}{l}56.50 * \\
{[0.000]}\end{array}$ & 1 & $\begin{array}{l}53.25^{*} \\
{[0.000]}\end{array}$ & 1 & $\begin{array}{l}41.39 * \\
{[0.000]}\end{array}$ & 3 & $\begin{array}{l}53.24 * \\
{[0.000]}\end{array}$ & 1 \\
\hline PCRGNP & $\begin{array}{l}49.22 * \\
{[0.000]}\end{array}$ & 2 & $\begin{array}{l}43.07 * \\
{[0.000]}\end{array}$ & 2 & $\begin{array}{l}49.86 * \\
{[0.000]}\end{array}$ & 2 & $\begin{array}{l}53.25 * \\
{[0.000]}\end{array}$ & 1 \\
\hline RGFCF & $\begin{array}{l}39.73 * \\
{[0.000]}\end{array}$ & 3 & $\begin{array}{l}37.53 * \\
{[0.000]}\end{array}$ & 3 & $\begin{array}{l}33.52 * \\
{[0.000]}\end{array}$ & 4 & $\begin{array}{l}44.20 * \\
{[0.000]}\end{array}$ & 2 \\
\hline EL & $\begin{array}{l}40.75^{*} \\
{[0.000]}\end{array}$ & 3 & $\begin{array}{l}34.99 * \\
{[0.000]}\end{array}$ & 3 & $\begin{array}{l}33.62 * \\
{[0.000]}\end{array}$ & 2 & $\begin{array}{c}31.18 * \\
{[0.000]}\end{array}$ & 3 \\
\hline OR & $\begin{array}{l}56.50 * \\
{[0.000]}\end{array}$ & 1 & $\begin{array}{l}53.25^{*} \\
{[0.000]}\end{array}$ & 1 & $\begin{array}{c}31.71 * \\
{[0.000]}\end{array}$ & 4 & $\begin{array}{c}31.84 * \\
{[0.000]}\end{array}$ & 3 \\
\hline INFDI & $\begin{array}{l}48.09 * \\
{[0.000]}\end{array}$ & 2 & $\begin{array}{l}35.45^{*} \\
{[0.000]}\end{array}$ & 3 & $\begin{array}{c}48.44^{*} \\
{[0.000]}\end{array}$ & 2 & $\begin{array}{c}45.23 * \\
{[0.000]}\end{array}$ & 2 \\
\hline OUTFDI & $\begin{array}{c}38.71 * \\
{[0.000]}\end{array}$ & 3 & $\begin{array}{c}33.40 * \\
{[0.000]}\end{array}$ & 3 & $\begin{array}{c}48.58^{*} \\
{[0.000]}\end{array}$ & 2 & $\begin{array}{c}45.51 * \\
{[0.000]}\end{array}$ & 2 \\
\hline Model-1 & $\begin{array}{c}1.023 \\
{[0.153]}\end{array}$ & 2 & $\begin{array}{c}1.023 \\
{[0.153]}\end{array}$ & 3 & $\begin{array}{c}-0.216 \\
{[0.586]}\end{array}$ & 2 & $\begin{array}{c}-0.216 \\
{[0.586]}\end{array}$ & 2 \\
\hline Model-2 & $\begin{array}{c}0.803 \\
{[0.211]}\end{array}$ & 3 & $\begin{array}{c}0.803 \\
{[0.211]}\end{array}$ & 3 & $\begin{array}{c}-0.981 \\
{[0.837]}\end{array}$ & 2 & $\begin{array}{l}-0.981 \\
{[0.837]}\end{array}$ & 2 \\
\hline
\end{tabular}

Note: The '*' mark before the CD-LMadj test statistics indicates the existence of cross section dependence at $1 \%$ significance level in relevant variables. Numbers on ' $L$ ' column refer to the optimal lag lengths determined with the Schwarz information criteria; the values in parenthesis ' $[$ ]' show the possibilities belong to test statistics. 


\section{Mll Macrothink}

The results in Table 2 indicate that the panel data analysis techniques which consider the cross section dependence and do not consider this dependence should be respectively used together for the next phases of the analyses for the groups of G-7 and EME-7 in terms of the cointegration equations of models and the variables in defined models. CADF (Cross-Sectional Augmented Dickey-Fuller) second generation panel unit root test of Pesaran (2007) that considers the cross section dependence investigates the steady state of the variables in models defined in two country groups. In this test, firstly the values of CADF test statistics are computed for all cross sections create the panel, immediately after the CIPS test (Cross-Sectionally Augmented IPS) statistical data are found by being used the arithmetic means of these values. The CADF test statistics provide significant results also under the conditions of $\mathrm{N}>\mathrm{T}$ and $\mathrm{N}<\mathrm{T}$ are calculated as follows:

$$
t(N, T)=\frac{\Delta y_{i}^{\prime} \bar{M}_{i} y_{i-1}}{\bar{\sigma}^{2}\left(\Delta y_{i-1}^{\prime} \bar{M}_{i} y_{i-1}\right)^{1 / 2}}
$$

After being computed the CADF test statistics values as is seen from Equation 3, the CIPS statistics values are calculated by averaging of these values as follows:

$$
C I P S=N^{-1} \sum_{i=1}^{n} t(N, T)
$$

The hypotheses are tested for stationarity by being compared the values of CADF and CIPS test statistics with the critical table values created by Monte Carlo simulations. At the end of the test, the basic hypothesis (there is the unit root in the series) is denied in case of being the values of CADF and CIPS test statistics bigger than critical table values, and the alternative hypothesis (there is not the unit root in series) is accepted for relevant panel-wide (Pesaran, 2007:265-312). In this research, the steady state of the variables used in models defined for the groups of G-7 and EME-7 is searched by CIPS Panel Unit Root test, and Table 3 shows the findings.

It is seen when the results of CIPS in intercept+trend forms in Table 3 are evaluated for the G-7 group that the OR variable is stationary at the level value while all other variables are stationary at first differences and 5\% significance level. Followed when the results of CIPS are evaluated in terms of the EME-7 group that the values of PCRGDP, PCRGNP, and OR in intercept form are stationary at the level value while all other variables are stationary at first differences and 5\% significance level. On the contrary, just the OR variable in intercept+trend form is stationary at level value; all other variables are stationary at first differences and 5\% significance level. This condition knowledgeable with being the CIPS statistics values computed in forms of intercept and intercept+trend bigger than critical table values at 0,05 significance level and denied the main hypothesizes. All these results refer that some of the series in models defined in the groups of G-7 and EME-7 are stationary at level value $[\mathrm{I}(0)]$, a significant part of these series become stationary at the first differences [I(1)], and finally the panels consist of integrated series from different levels. 
Table 3. Results of CIPS Panel Unit Root Test

\begin{tabular}{ccccccc}
\hline Intercept & \multicolumn{3}{c}{ G-7 } & \multicolumn{3}{c}{ EME-7 } \\
\hline Variables & Level & 1st. Difference & L & Level & 1st. Difference & L \\
\hline PCRGDP & -2.09 & $-3.42^{*}$ & 1 & $-2.61^{*}$ & $-2.47^{* *}$ & 3 \\
PCRGNP & -2.25 & $-3.42^{*}$ & 2 & $-2.61^{*}$ & $-2.47^{* *}$ & 2 \\
RGFCF & -2.06 & $-3.35^{*}$ & 3 & -1.94 & $-2.35^{* *}$ & 4 \\
EL & -1.81 & $-3.14^{*}$ & 3 & -2.24 & $-4.10^{*}$ & 2 \\
OR & $-3.61^{*}$ & $-5.52^{*}$ & 1 & $-3.06^{*}$ & $-3.49^{*}$ & 4 \\
INFDI & -2.25 & $-3.66^{*}$ & 2 & -1.81 & $-2.98^{*}$ & 2 \\
OUTFDI & -1.34 & $-4.12^{*}$ & 3 & -1.43 & $-3.07^{*}$ & 2 \\
\hline
\end{tabular}

\begin{tabular}{|c|c|c|c|c|c|c|}
\hline Intercept+Trend & & G-7 & & & EME-7 & \\
\hline Variables & Level & 1st. Difference & $\mathrm{L}$ & Level & 1st. Difference & $\mathbf{L}$ \\
\hline PCRGDP & -2.40 & $-3.32 *$ & 1 & -2.34 & $-4.02 *$ & 1 \\
\hline PCRGNP & -2.61 & $-3.35 *$ & 2 & -2.51 & $-2.99 * *$ & 1 \\
\hline RGFCF & -2.44 & $-3.37 *$ & 3 & -2.31 & $-4.30 *$ & 2 \\
\hline EL & -2.24 & $-3.12 * *$ & 3 & -2.56 & $-3.36^{*}$ & 3 \\
\hline OR & $-4.09 *$ & $-5.36^{*}$ & 1 & $-2.91 * *$ & $-4.35^{*}$ & 3 \\
\hline INFDI & -2.26 & $-3.73 *$ & 3 & -2.01 & $-2.89 * *$ & 2 \\
\hline OUTFDI & -2.07 & $-4.12 *$ & 3 & -1.56 & $-3.34 *$ & 2 \\
\hline \multirow{3}{*}{\multicolumn{2}{|c|}{ CIPS Critical Table Values }} & & \multicolumn{2}{|c|}{ Intercept } & \multicolumn{2}{|c|}{ Intercept+Trend } \\
\hline & & $(\%$ 1) & \multicolumn{2}{|r|}{-2.60} & \multicolumn{2}{|l|}{-3.15} \\
\hline & & $(\% 5)$ & \multicolumn{2}{|r|}{-2.34} & \multicolumn{2}{|l|}{-2.88} \\
\hline
\end{tabular}

Note: Marks of '*' and '**' before the CIPS statistics indicate that the variables are respectively stationary at $1 \%$ and $5 \%$ significance level. The critical table values of CIPS statistics are received from the research of Pesaran (2007). Please see the explanations about ' $L$ ' column in Table 2.

While the transitory shocks did not leave an impression at a level value in stationary series in the past, the impacts of transitory shocks may be permanent for the series became stationary at their first levels. This circumstance can also remove the integrated relations which are possible to happen in the long term between integrated series from different degrees. Therefore, much as the economic series are stationary at different levels, a composition can be found where these series are integrated, and cointegration analyses specify this case (Tar1, 2010: 415). The panel cointegration tests provide consistent results for models have not the cross section dependence (Johansen 1988; Kao 1999; Pedroni 1999, etc.); again panel cointegration tests produce correct and consistent results in the case of being cross section dependence in co-integration equations (Westerlund and Edgerton 2007, Westerlund 2008, etc.). After all, the long termed possible relations between variables in models consisting of integrated series at different levels and have cross sections independent from each other can be analyzed by Westerlund (2008) Durbin-Hausman Panel Co-Integration test. 
Durbin-Hausman Panel Co-Integration test that can also be used in cases of being the cross section units are interdependent or independent of each other enables for reviewing the long termed relations and considers the common factors in panel in the event of being the dependent variable [I(1)], independent variable [I(1)] and [I(0)]. Long termed cointegration relations can be analyzed at panel and group scale in a Durbin-Hausman method that can compute different test statistics for the hypothesis considers both panel homogeneity and panel heterogeneity. Accepted in $\mathrm{DH}(\mathrm{DHg})$ group test that the autoregressive parameter changes between the sections while this autoregressive parameter remains same for all sections in $\mathrm{DH}$ (DHp) panel test. It is understood that there is the cointegration relation respectively in some sections and all sections create the panel when the HO basic hypothesizes are denied in DH group and DH panel tests. H0 basic hypothesizes accepted or denied after being compared the test statistics with normal distribution critical table values. If the test statistics computed for DHp and DHg tests bigger than the normal distribution critical table values (2.33), the $\mathrm{H} 0$ basic hypothesis is denied at $1 \%$ significance level, and the existence of cointegration relation in some and all sections create the panel is accepted (Westerlund, 2008: 196-199). In this study, the presence of long termed relationships between the variables in models defined in the groups of G-7 and EME-7 is reviewed by Durbin-Hausman Panel Co-Integration test and Table 4 shows the results.

Table 4. Results of Durbin-Hausman Panel Co-Integration Test

\begin{tabular}{ccccc}
\hline & G-7 & & \multicolumn{2}{c}{ EME-7 } \\
\hline DH-Test Statistics & Model-1 & Model-2 & Model-1 & Model-2 \\
\hline $\mathrm{DH}_{\mathrm{g}}$ & $6.086^{*}[0.000]$ & $3.392^{*}[0.000]$ & $8.885^{*}[0.000]$ & $6.130 *[0.000]$ \\
$\mathrm{DH}_{\mathrm{p}}$ & $8.116^{*}[0.000]$ & $9.074 *[0.000]$ & $2.610^{*}[0.005]$ & $4.158^{*}[0.000]$ \\
\hline
\end{tabular}

Note: '*' mark before the test statistics means there is the cointegration relation between the series in a model at $1 \%$ importance level. The intercept+trend form obtains Durbin-Hausman test statistics by considering the stable condition of the series in models defined in G-7 and EME-7 groups. The numbers in square brackets '[ ]' show the possibility values belong to the test statistics.

It is observed when the results in Table 4 are analyzed that the main hypothesizes are denied at $1 \%$ significance level based on the DHp and DHg test statistics in all models defined in G-7 and EME-7 groups, then the alternative hypothesizes are accepted. These results refer that there is a long termed cointegration relation between the series in all cross section units create the panel and defined models for G-7 and EME-7 groups; the integrated series at different levels tend to follow the similar trends in the long term.

After being determined the long termed relations between series in described models, the long termed coefficients belong to series can be estimated. In this research, determining the cross sections in models defined for the groups of G-7 and EME-7 are independent of each other, and the series are integrated at different levels necessitate being predicted the long termed coefficients belong to series in models via the method of Panel ARDL (Autoregressive Distributed Lag). The Panel ARDL method that was developed as an error 
correction model by Pesaran et al., (1999) based on two different group estimators called Mean Group (MG) and Pooled Mean Group (PMG). The long termed coefficients in MG estimator are obtained by being calculated the unweighted mean of the coefficients derived from individual predictions of ARDL and without imposing any restriction on the coefficients in ARDL specification. On the other hand, the long termed coefficients in PMG estimator are obtained by being calculated the unweighted mean of the coefficients derived from specific predictions of ARDL and imposed restrictions on the coefficients in ARDL specification. When viewed from this aspect, the short and long termed coefficients create the panel are not accepted as homogeneous in MG estimator. Due to being allowed for the constant term, variances of error term and short term coefficients to change, the coefficients are accepted as heterogeneous in short term and homogeneous in the long term. A lagged Panel ARDL method with two variables are calculated by below equations:

$Y_{i t}=\alpha_{i}+\sum_{j=1}^{p} \beta_{i j} Y_{i t-j}+\sum_{j=0}^{q} \delta_{i j} X_{i t-j}+\varepsilon_{i t}$

$Y_{i t}$ In here (i) concept shows the cross section units of the panel; (t) term indicates the time dimension of the panel. The short and long term parameters about Panel ARDL technique are estimated by being written the equation in Equality 5 as the error correction model as follows:

$$
\Delta Y_{i t}=\alpha_{i}+\sum_{j=1}^{p-1} \beta_{i j} \Delta Y_{i t-j}+\sum_{j=0}^{q-1} \delta_{i j} \Delta X_{i t-j}+\sigma_{i} Y_{i t-1}+\varphi_{i} X_{i t}+\varepsilon_{i t}
$$

The Term of $(\Delta)$ in the equation represents the difference processor and $(\sigma=-(1-$ $\left.\left.\sum_{j=1}^{p} \beta_{i j}\right)\right)$ term shows the coefficient of error correction. While the parameters obtained from level values of variables show the long termed coefficients in Table 5, the parameters derived from first differences of variables state the short termed variables in Table 6. Being the error correction term $(\sigma)$ coefficient negative and statistically significant show that the effect of a temporary shock happened in variables will regenerate in the long term and the interactive walking of variables will find the balance as well. Moreover, Hausman Test may be helpful to find the best and unbiased estimator among from the estimators of PMG or MG in Panel ARDL method. Pesaran et al., (1999: 621-634). The central hypothesis called 'long termed coefficients are homogeneous' cannot be denied at $5 \%$ importance level in case of being the probability values of test statistics calculated at the end of the Hausman Test bigger than 0,05 , and discussed that the PMG estimator is the unbiased and efficient estimator. In this research, the effects of foreign direct investment inflows/outflows on the economic growth are estimated by PMG method and Hausman Test for the models defined in G-7 and EME-7 groups, Table 5 and Table 6 show the results. 
Table 5. Results of PMG Estimations

\begin{tabular}{|c|c|c|c|c|}
\hline Model-1 & \multicolumn{2}{|c|}{ G-7 } & \multicolumn{2}{|c|}{ EME-7 } \\
\hline Long Run Coefficients & Coefficient & Standard Error & Coefficient & Standard Error \\
\hline RGFCF & $0.2768 *$ & $0.0323[0.000]$ & $0.2277 *$ & $0.0210[0.000]$ \\
\hline EL & 0.0599 & $0.1192[0.616]$ & $0.2495 *$ & $0.0862[0.005]$ \\
\hline OR & $0.1802 *$ & $0.0217[0.000]$ & $0.2174 *$ & $0.0341[0.000]$ \\
\hline INFDI & $0.0980 *$ & $0.0353[0.006]$ & $0.5987 *$ & $0.0837[0.000]$ \\
\hline $\operatorname{ECC}(\sigma)$ & $-0.7944 *$ & $0.1179[0.000]$ & $-0.2943 * *$ & $0.1375[0.034]$ \\
\hline Short Run Coefficients & Coefficient & Standard Error & Coefficient & Standard Error \\
\hline$\triangle \mathrm{RGFCF}$ & 0.0094 & $0.0357[0.794]$ & $0.1227 *$ & $0.0442[0.006]$ \\
\hline$\Delta \mathrm{EL}$ & $0.2757 * *$ & $0.1225[0.026]$ & $0.1665 * *$ & $0.0714[0.021]$ \\
\hline$\Delta \mathrm{OR}$ & 0.0083 & $0.0223[0.709]$ & 0.0075 & $0.0304[0.806]$ \\
\hline$\triangle \mathrm{INFDI}$ & -0.0396 & $0.0441[0.371]$ & 0.0369 & 0.3428 [0.915] \\
\hline No Observations & \multicolumn{2}{|c|}{147} & \multicolumn{2}{|c|}{147} \\
\hline \multicolumn{5}{|l|}{ Diagnostic Tests } \\
\hline Hausman Test & \multicolumn{2}{|c|}{$3.39[0.495]$} & \multicolumn{2}{|c|}{$3.45[0.485]$} \\
\hline Log Likelihood & \multicolumn{2}{|c|}{-134.69} & \multicolumn{2}{|c|}{-214.08} \\
\hline Jarque-Bera & \multicolumn{2}{|c|}{$0.544^{\mathrm{a}}[0.762]$} & \multicolumn{2}{|c|}{$3.691^{\mathrm{a}}[0.158]$} \\
\hline
\end{tabular}

Note: The marks of '*' and '**' before the coefficients computed for the variables indicate that the $\mathrm{t}$-statistics belong to coefficients are respectively meaningful at $1 \%$ and $5 \%$ levels. The optimal lag lengths for variables and the maximum lag lengths for defined models are determined base on Schwarz information criteria. The values in square brackets show the probability values belong to coefficients and related tests. The mark of "a" before the Jarque-Bera test statistics refers that the series in models have a standard distribution.

It is seen when the long termed PMG results in Table 5 are analyzed that the coefficients of explanatory variables of RGFCF, EL, OR and INFDI in G-7 and EME-7 groups are positively inclined and meaningful at $1 \%$ significance level (except EL variable in G-7 group) as expected. These results prove that the increments happened in physical human capital accumulation, openness degree and foreign direct investment inflows in G-7 and EME-7 groups affect the economic growth (real GDP) positively and statistically significant (except human capital accumulation in G-7 group). However, when the long termed PMG results in Table 5 are analyzed in terms of INFDI variable, the coefficients of INFDI variable in G-7 and EME-7 groups is respectively calculated as (0.0980) and (0.5987). On one hand, these results confirm that the effects of foreign direct investment inflows in both two country groups on the economic growth are positively inclined, on the other hand, these same results show that the size of positively inclined effects are about six times more in EME-7 group than G-7 group as expected. It is observed when the results of PMG in Table 5 are analyzed in terms of the short term that the EL variable in G-7 group and just RGFCF, EL variables in the EME-7 group have a positive and statistically significant effect on the economic growth. When the results in Table 5 are examined regarding error correction coefficients (ECC), seen that the EEC coefficients in G-7 and EME-7 groups are respectively calculated as (-0.79) and 
$(-0.29)$ and statistically significance at different importance levels as well. Being the coefficients of ECC negative and statistically significant means that the effect of a temporary shock happened in variables in the short term will regenerate in the long term and the interactive walking of variables will find the balance as well.

Table 6. Results of PMG Estimations

\begin{tabular}{ccccc}
\hline Model-2 & \multicolumn{2}{c}{ G-7 } & \multicolumn{2}{c}{ EME-7 } \\
\hline Long Run Coefficients & Coefficient & Standard Error & Coefficient & Standard Error \\
\hline RGFCF & $0.2560^{*}$ & $0.0360[0.000]$ & $0.3563^{*}$ & $0.0290[0.000]$ \\
EL & -0.0708 & $0.1317[0.592]$ & $0.4618^{*}$ & $0.1364[0.001]$ \\
OR & $0.2255^{*}$ & $0.0239[0.000]$ & 0.0601 & $0.0379[0.116]$ \\
OUTFDI & $0.0665^{* *}$ & $0.0271[0.015]$ & 0.1738 & $0.1938[0.372]$ \\
ECC $(\sigma)$ & $-0.8412^{*}$ & $0.1533[0.000]$ & $-0.5048^{*}$ & $0.1442[0.000]$ \\
\hline Short Run Coefficients & Coefficient & Standard Error & Coefficient & Standard Error \\
\hline$\Delta$ RGFCF & 0.0172 & $0.0444[0.700]$ & 0.0278 & $0.0323[0.391]$ \\
$\Delta$ EL & $0.2952^{*}$ & $0.0788[0.003]$ & 0.1028 & $0.1352[0.448]$ \\
$\Delta$ OR & -0.0309 & $0.0407[0.448]$ & 0.0128 & $0.0274[0.641]$ \\
$\Delta$ OUTFDI & 0.0759 & $0.1372[0.581]$ & -0.1911 & $0.2119[0.369]$ \\
No Observations & \multicolumn{2}{c}{147} & & 147 \\
Diagnostic Tests & \multicolumn{3}{c}{$0.92[0.922]$} & $3.07[0.546]$ \\
Hausman Test & -156.08 & & -250.65 \\
Log Likelihood & $0.016^{\mathrm{a}}[0.992]$ & $2.500^{\mathrm{a}}[0.286]$ \\
Jarque-Bera & & &
\end{tabular}

Note: Please see the explanations in Table 5.

It is seen when evaluating the long termed PMG results in Table 6 that the coefficients of explanatory variables of RGFCF, EL, and OR in G-7 and EME-7 groups are mostly active and significant at 1\% importance level (except EL in G-7 group and OR in EME-7 group). These results reveal that the increments actualized in physical capital accumulation and an openness degree in the G-7 group have a positive and statistically significant effect on the economic growth (real GNP). Results also show that the increments actualized in physical and human capital accumulation (improvements) in the EME-7 group have a positive and statistically substantial effect on the economic growth. Moreover, the results confirm that the physical capital accumulation in G-7 growth and the openness degree in the EME-7 group have not an important effect (statistically insignificant) on economic growth. When the long termed results of PMG in Table 6 are evaluated in terms of OUTFDI variable in the model, it can be easily said that the coefficient of this variable calculated as (0.0665) in G-7 group and (0.1938) in EME-7 group is positive and statistically significant and insignificant respectively. These results reveal that the increments actualized in foreign direct investment outflows effect the economic growth (real GNP) in G-7 group positively and statistically 


\section{MlMacrothink}

significant, but these outflows have not any effect on the economic growth of the EME-7 group. So, we can understand that the existed differences based on the long termed effects of foreign direct investment outwards on the economic growth of G-7 and EME-7 turn into an absolute superiority.

When the conclusions in Table 6 are analyzed concerning the short term, it is seen that just EL variable in G-7 group has a positive and statistically significant effect on the economic growth; neither of the variables in the EME-7 group has an effect on the economic growth. We can see if the results in Table 6 are analyzed in ECC that the coefficients of ECC respectively calculated as (-0.84) and (-0.50) in the groups of G-7 and EME-7 are statistically significant at $1 \%$ level. Being the coefficients of ECC negative and statistically significant refers that the effect of a temporary shock happened in variables of defined model in the short term will regenerate in the long run and the interactive walking of variables will find the balance as well.

Table 7. Results of Dumitrescu and Hurlin Panel Causality Test

\begin{tabular}{ccccccccc}
\hline & \multicolumn{3}{c}{ G-7 } & \multicolumn{5}{c}{ EME-7 } \\
\hline Test Statistics & W-Stat. & Zbar-Stat. & L & Prob. & W-Stat. & Zbar-Stat. & L & Prob. \\
\hline PCRGDP $\rightarrow$ INFDI & 1.17 & 0.06 & 1 & 0.945 & $3.02^{*}$ & $2.85^{*}$ & 1 & 0.004 \\
INFDI $\rightarrow$ PCRGDP & $3.41^{*}$ & $3.44^{*}$ & 1 & 0.000 & 0.84 & -0.43 & 1 & 0.667 \\
PCRGNP $\rightarrow$ OUTFDI & 1.91 & 1.18 & 1 & 0.237 & 0.80 & -0.49 & 1 & 0.623 \\
OUTFDI $\rightarrow$ PCRGNP & $3.66^{*}$ & $3.83^{*}$ & 1 & 0.000 & 0.49 & -0.96 & 1 & 0.335 \\
\hline
\end{tabular}

Note: The '*' mark before the test statistics means that there is a causality relation between the variables at $1 \%$ significance level. ' $\mathrm{L}$ ' column in Table shows the lag lengths for the variables, the values in square brackets '[ ]' show the probability values belong to test statistics.

In defined models, after being specified the short and long termed effects of foreign direct investment inflows/outflows on the economic growth, the direction of relations between related variables can be examined by causality tests. Herein, Dumitrescu and Hurlin (2012) Panel Causality test that can be used in cases where the cross sections are interdependent and independent investigates the direction of the causality relations between foreign direct investment inflows/outflows and economic growth. In Dumitrescu and Hurlin (2012) Panel Causality test that can produce consistent results for also unbalanced panels, the causality relations between the variables are researched by test statistics of (W) and (Zbar) calculated by Monte Carlo simulations. One of the main hypothesis called 'there is not a causality relation between series in all cross sections' is denied when the probability values belong to test statistics are smaller than 0.01, and the alternative hypothesis called 'there is causality relation between series in some of the cross sections' is accepted (Dumitrescu and Hurlin, 2012: 1450-60). At this stage, it is discussed that there are causality relations between relevant variables in at least some of the cross sections create the panel. Table 7 shows the results of Dumitrescu and Hurlin Panel Causality test that analyzes the relations between 
foreign direct investment inwards/outwards and the economic growth in the models defined in G-7 and EME-7 groups.

It is seen when the results in Table 7 are analyzed that there is a one-way causality relation performs from foreign direct investment inflows and outflows to the economic growth between the foreign direct investment inflows/outflows and the economic growth in G-7 group. When the results in Table 7 are analyzed in EME-7 group, seen that there is a one-way causality relation performs from the economic growth to foreign direct investment inflows between just the foreign direct investment inflows and the economic growth. This status is understood by being the probabilities belong to test statistics calculated for the related variables smaller than 0.01 . These conclusions confirm that the increments in foreign direct investment inflows/outflows in G-7 group accelerate the economic growth while just the increments in economic growth increase the foreign direct investment inflows in the EME-7 group.

\section{Conclusion}

The foreign direct investment inflows/outflows enable for the capital exporter/importer countries to close their saving gaps, use the national over savings and increase the fixed capital investments at the home or abroad. From this aspect, the foreign direct investment inflows/outflows pave the way for the capital exporter/importer countries to respectively increase their Real Gross Domestic Product and Real Gross National Product

From this viewpoint, the effects of foreign direct investment inflows/outflows on the economic growth are econometrically analyzed in this study for the period of 1994-2015 for G-7 countries where the capital mobility is full and EME-7 countries which are developing and selected emerging market economies. Additionally, the relations between foreign direct investment inflows-outflows and the economic growth are researched by being considered the effects of foreign direct investment inflows on real GDP and foreign direct investment outflows on real GNP. It is also econometrically analyzed in this study that whether the inflows and outflows of foreign direct investments in countries of G-7 and EME-7 have an effect on the economic growth as is seen in the theoretical framework by being considered the capital exporter/importer positions of these countries. The models established with physical human capital accumulation and control variables of openness degree for analyzing the long termed effects of foreign direct investment inflows on real GDP and outflows on real GNP are estimated within the scope of new generation panel data methodology considers the cross section dependence. At the end of the study, it is possible to express the results which are compatible with the theoretical framework and the empirical literature obtained from the models defined for both two country groups as follows.

It is determined that the foreign direct investment inflows in G-7 and EME-7 countries have a positive and statistically significant effect on the economic growth (real GDP) in the long term when being considered the capital importer positions of these countries. Furthermore, the size of positively inclined and statistically significant effects of foreign direct investment 
inflows on the economic growth is about six times more in EME-7 group than the G-7 group as expected. These results show that the foreign direct investment inflows in the EME-7 group had a crucial role for being financed the real GDP and increased the domestic production possibilities by closing the saving gaps and the connection between foreign direct investment inflows and the economic growth is relatively stronger.

It is seen when the capital exporter position of G-7 countries is considered that the foreign direct investment outflows effect the economic growth (real GNP) in G-7 group positively and statistically significant in the long term, but these outflows have not any effect on economic growth of the EME-7 group. So, we can understand that the existed differences based on the long termed effects of foreign direct investment outwards in developed G-7 countries and developing EME-7 countries on the economic growth turned into an absolute superiority. These results show that the foreign direct investment outflows in the G-7 group had a crucial role for being financed the real GNP and increased the production possibilities abroad by using the national over savings and the connection between foreign direct investment outflow and the economic growth is much stronger. All these results show that the foreign direct investment outflows have an important role for G-7 countries to use the national over savings and the foreign direct investment inflows play the more effective role for EME-7 countries to close the saving gaps at the same time.

The size of the long termed effects of the foreign direct investment inflows/outflows on the variables of economic growth is also confirmed regarding the direction of causality relations between the variables. Within this context, it is determined that there is a one-way causality link performs from foreign direct investment inflows/outflows to the variables of economic growth between the foreign direct investment inflows/outflows and the economic growth variables in G-7 group. On the contrary, there is a one-way causality relation performs from the variable of economic growth to foreign direct investment inflows between just the foreign direct investment inflows and the economic growth variable. These results prove that the increments actualized in foreign direct investment inflows/outflows increase the Real Gross Domestic Product/Real Gross National Product in G-7 group while just the increments in Real Gross Domestic Product increase the foreign direct investment inflows in the EME-7 group.

All these results obtained from the research show that both the foreign direct investment inflows and outflows play a major role in economic growth of developed G-7 countries while just the foreign direct investment inflows have this important role in economic growth of EME-7 countries. These results also show parallelism with the development levels of countries make us think that G-7 countries have a high potential for producing and exporting the innovative process products via foreign direct investments; EME-7 countries have not an effectiveness like this at present. In this context, the policy makers in countries of EME-7 groups need to develop long termed policies for being increased the national level of savings and exported the innovative process products create added value via foreign direct investments. In this way, it will be possible to improve the foreign direct investment inflows as quantitative and qualitative in the economies of the EME-7 group, strengthen the connection of these inflows with the economic growth and reduce the differences even a little 
between G-7 and EME-7 countries. In addition to all these, it is thought that being conducted the empirical studies to specify the determinants of foreign direct investment inflows/outflows will contribute to the improvement of the literature on this point.

\section{References}

Alfaro, L., \& Charrlton, A. (2007). Growth and The Quality of Foreign Direct Investment: Is All FDI Equal?. Centre for Economic Performance, London School of Economics, CEP Discussion Papers, No: 830.

Al-Shawaf, A., Mohammed, K., \& Almsafir, M. K. (2016). Economic globalization: role of inward and outward FDI with economic growth-evidence from Malaysia. Journal of Business and Retail Management Research, 10(2), 64-74.

Balasubramanyam, V. N., Salisu, M., \& Sapsford, D. (1996). Foreign Direct Investment and Growth in EP and IS Countries. The Economic Journal, 109(434), 92-105. http://dx.doi.org/10.2307/2234933

Bayraktar, F. (2003). Foreign Direct Investments in Turkey and the World. Turkey Development Bank Headship of General Surveys.

Behbehani, M., \& Hallaq, S. (2013). Impact of Home Country Outward Foreign Direct Investment on Its Economic Growth: A case of Kuwait. Asian Journal of Business and Management Sciences, 3(3), 19-33.

Borensztein, E., Gregorio, J., \& De, L. J-W. (1998). How Does Foreign Direct Investment Affect Economic Growth?. Journal of International Economics, 45, 115-135. http://dx.doi.org/10.1016/S0022-1996(97)00033-0

Bosworth, B., \& Collins, S. M. (1999). Capital Inflows, Investment and Growth. Tokyo Club Papers, 12, 35-74.

Breitung, J. (2005). A Parametric Approach to The Estimation of Cointegration Vectors in Panel Data. Econometric Reviews, 24(2), 151-173. http://dx.doi.org/10.1081/ETC-200067895

Breuer, Janice B., Robert, M., \& Myles, W. (2002). Series-Specific Unit Root Tests with Panel Data. Oxford Bulletin of Economics and Statistics, 64(5), 527-546. http://dx.doi.org/10.1111/1468-0084.00276

Carkovic, M. V., \& Levine, R. (2002). Does Foreign Direct Invesment Accelerate Growth?. $\mathrm{U}$ of Minnesota Department of Finance Working Paper. http://dx.doi.org/10.2139/ssrn.314924

Chen, Jen-E., Zulkifli, S., \& Azreen. M. (2012). Malaysian Outward FDI and Economic Growth. International Congress on Interdisciplinary Business and Social Science, (ICIBSoS 2012). Procedia-Social and Behavioral Sciences, 65, 717-722. https://doi.org/10.1016/j.sbspro.2012.11.189 


\section{Macrothink}

Research in Applied Economics

ISSN 1948-5433

2017, Vol. 9, No. 1

Chowdhary, R., \& Kushwaha, V. (2013). Domestic Investment, Foreign Direct Investment and Economic Growth in India Since Economic Reforms. Journal of Transformative Entrepreneurship, 1(2), 74-82.

De Mello, L. R. (1999). Foreign Direct Investment Led Growth: Evidence From Time Series and Panel Data. Oxford Economic Papers, 51(1), https://doi.org/10.1093/oep/51.1.133

Dumitrescu, E. I., \& Hurlin, C. (2012). Testing for Granger Non-Causality in Heterogeneous Panels. Economic Modelling, 29(4), 1450-1460. http://dx.doi.org/10.1016/j.econmod.2012.02.014

Hadri, K., \& Kurozumi, E. (2012). A Simple Panel Stationarity Test in the Presence of Serial Correlation and a Common Factor. Economics Letters, 115, 31-34. http://dx.doi.org/10.1016/j.econlet.2011.11.036

Hadri, K., (2000). Testing for Stationarity in Heterogeneous Panels. Econometrics Journal, 3, 148- http://dx.doi.org/161. 10.1111/1368-423X.00043

Hermes, N., \& Lensink, R. (2003). Foreign Direct Investment, Financial Development and Economic Growth. The Journal of Development Studies, 40(1), 142-163. http://dx.doi.org/10.1080/00220380412331293707

Herzer, D. (2008). The long-run relationship between outward FDI and domestic output: evidence from panel data. Economic Letters, 100, 146-149. http://dx.doi.org/10.1016/j.econlet.2007.12.004

Im, Kyung, S., Pesaran M. H., \& Shin, Y. (2003). Testing for Unit Roots in Heterogeneous $\begin{array}{llll}\text { Panels. Journal of } & \text { Econometrics, } & \text { 115(1), }\end{array}$ http://dx.doi.org/10.1016/S0304-4076(03)00092-7

Johansen, S. (1988). Statistical Analysis of Cointegration Vectors. Journal of Economic Dynamics and Control, 12(2), 231-254. https://doi.org/10.1016/0165-1889(88)90041-3

Kao, C. (1999). Spurious Regression and Residual-Based Tests for Cointegration in Panel Data. Journal of Economerics, $\quad 90(1), \quad$ 1-44. http://dx.doi.org/10.1016/S0304-4076(98)00023-2

Khawar, M. (2005). Foreign Direct Investment and Economi Growth: A Cross-Country Analysis. Global Economy Journal, 5(1), 1-11. https://doi.org/10.2202/1524-5861.1057

Kumar N., \& Pradhan, P. (2002). Foreign Direct Investment, Externalities and Economic Growth in Developing Countries. RIS Discussion Papers, No: 1, 1-37.

Lee, C. G. (2010a). Outward foreign direct investment and economic growth: evidence from Japan. Global Economic Review, 39(3), 317-326. http://dx.doi.org/10.1080/1226508X.2010.513143

Lee, C. G. (2010b). The nexus of outward foreign direct investment and income: evidence from Singapore. Applied Econometrics and International Development, 10(1), 187-194. 


\section{Mll Macrothink}

Lensink, R., \& Morrissey, O. (2006). Foreign Direct Investment: Flows, Volatility, and the Impact on Growth. Review of International Economics, 14(3), 478-493. http://dx.doi.org/10.1111/j.1467-9396.2006.00632.x

Levin, A., Lin, C-F., \& Chu, Chia-Shang J. (2002). Unit Root Tests in Panel Data: Asymptotic and Finite-Sample Properties. Journal of Econometrics, 108(1), 1-24. http://dx.doi.org/10.1016/S0304-4076(01)00098-7

Li, X., \& Liu, X. (2004). Foreign Direct Investment and Economic Growth: An Increasingly Endogenous Relationship. World Development, 33(3), 393-407. http://dx.doi.org/10.1016/j.worlddev.2004.11.001

Mun, H. W., Lin, T. K., \& Man, Y. K. (2008). FDI and Economic Growth Relationship: An Empirical Study on Malaysia. International Business Research, 1, 11-18.

Obwona, M. B. (2001). Determinants of FDI and their Impact on Economic Growth in Uganda. African Development Review, 13(1), 46-81. http://dx.doi.org/10.1111/1467-8268.00030

Panyagometh, K. (2016). Benefit Assessment of Outward Foreign Direct Investment On The Economic Growth: A Case Of Thailand. IJABER, 14(1), 329-338.

Pedroni, P. (1999). Critical Values for Cointegration Tests in Heterogeneous Panels with Multiple Regressors. Oxford Bulletin of Economics and Statistics, 61(1), 653-670.

Pesaran, M. H. (2007). A Simple Panel Unit Root Test in The Presence of Cross-Section Dependence. Journal of Applied Econometrics, 22(2), 265-312. http://dx.doi.org/10.1002/jae.951

Pesaran, M. H., Shin, Y., \& Smith, R. P. (1999). Pooled Mean Group Estimation of Dynamic Heterogeneous Panels. Journal of the American Statistical Association, 94(446), 621-634. http://dx.doi.org/10.1080/01621459.1999.10474156

Pesaran, M. H., Ullah, A., \& Yamagata, T. (2008). A Bias-Adjusted LM Test of Error CrossSection Independence. The Econometrics Journal, 11(1), 105-127. http://dx.doi.org/10.1111/j.1368-423X.2007.00227.x

Sarkar, P. (2007). Does Foreign Direct Investment Promote Growth? Panel Data and Time Series Evidence From Less Developing Counries 1970-2002. MPRA Paper, No: 5176.

Tarı, R. (2010). Econometric, Umuttepe Publishing, (6th Edition), Turkey: Kocaeli.

Tatoğlu, F. Y. (2013). Advanced Panel Data Analysis-Stata Practical, Beta Publishings, (2nd Edition). Turkey: Istanbul.

Taylor, M. P., \& Sarno, L. (1998). The Behavior of Real Exchange Rates During The Post-Bretton Woods Period. Journal of International Economics, 46(2), 281-312. http://dx.doi.org/10.1016/S0022-1996(97)00054-8 
Westerlund, J. (2008). Panel Cointegration Tests of the Fisher Effect. Journal of Applied Econometrics, 23(2), 193-233. http://dx.doi.org/10.1002/jae.967

Westerlund, J., \& Edgerton, D. L. (2007). A Panel Bootstrap Cointegration Test. Economics Letters, 97(3), 185-190. http://dx.doi.org/10.1016/j.econlet.2007.03.003

Zekarias, S. M. (2016). The Impact of Foreign Direct Investment (FDI) on Economic Growth in Eastern Africa: Evidence from Panel Data Analysis. Applied Economics and Finance, 3(1), 145-160. https://doi.org/10.11114/aef.v3i1.1317

\section{Notes}

Note 1. The countries covered in this study are: Australia, Austria, Canada, Denmark, Finland, France, Germany, Italy, Japan, Netherlands, Spain, Sweden, United Kingdom and United States.

Note 2. Being provided the data of FDI from WB database since 1994 is effective to choose this year as the start of the investigation period.

Note 3. The variables of PCRGDP and PCRGNP are used in the purchasing power parity from the WB database. The variable of RGFCF is used in per capita values by proportioning to total population obtained from WB database. OR variable is obtained by being proportioned the total of real goods-services exportation values of counties to the variable of real (2010) GDP in the same database. Moreover, the same data used for China is received as nominal and made real by the GDP deflator of the company. Variable of EL is obtained by being proportioned the labor employed to the total population in the same database. INFDI variable is found by being proportioned the net inflows to the variable of nominal GDP received from the same database. OUTFDI variable is obtained by being proportioned the net outflows to the nominal GNP variable received from the same database. The variables defined in Table are respectively used in analyses in shares in GDP and GNP, all other variables are used with the annual growth rate values in the analysis in research period.

Note 4. The studies of Lee (2010a), Behbehani and Hallaq (2013) and Panyagometh (2016) were useful to determine the variables in models established to review the effects of foreign direct investment netflows and outflows. Gauss 10.0 and Stata 14.00 econometric package programs were used to estimate the models defined in the study.

\section{Copyright Disclaimer}

Copyright for this article is retained by the author(s), with first publication rights granted to the journal.

This is an open-access article distributed under the terms and conditions of the Creative Commons Attribution license (http://creativecommons.org/licenses/by/3.0/). 